\title{
Determination of molecular weight of a purified fraction of colloidal calcium phosphate derived from the casein micelles of bovine milk
}

\author{
J. Choi, D. S. Horne, and J. A. Lucey ${ }^{1}$ \\ Department of Food Science, University of Wisconsin-Madison, 1605 Linden Drive, Madison 53706
}

\begin{abstract}
Colloidal calcium phosphate (CCP) plays a key role in the formation and integrity of casein $(\mathrm{CN})$ micelles. However, limited information is available on the molecular weight $\left(\mathrm{M}_{\mathrm{w}}\right)$ of CCP. Recently, we theoretically derived the $\mathrm{M}_{\mathrm{w}}$ of $\mathrm{CCP}$ and the objectives of this study were to experimentally determine the $\mathrm{M}_{\mathrm{w}}$ of CCP. We used 2 methods to prepare CCP fractions: skim milk was enzymatically digested with either trypsin or a combination of papain and proteinase enzymes to remove most $\mathrm{CN}$. The CN phosphopeptides are resistant to trypsin hydrolysis. Digestion was carried out in a membrane tube that was dialyzed against the same bulk milk used in sample preparation to remove small peptides and to minimize perturbation of CCP. After digestion, the protein contents of the enzyme-treated milks were 0.92 and $0.36 \%$ for the trypsin and papain-proteinase treatments, respectively. Size-exclusion chromatography, coupled with multi-angle laser light scattering, was used to separate the CCP-phosphopeptide fraction from the digested mixture. Simulated milk ultrafiltrate was used as a mobile phase during size-exclusion chromatography separation to try to preserve the integrity of CCP. Size-exclusion chromatography peaks, which had higher $\mathrm{Ca}$ and $\mathrm{P}$ contents than the baseline, were identified as the likely fractions containing the phosphopeptidestabilized CCP; this peak eluted with retention times of 100 to approximately 110 min for trypsinated samples. The papain-proteinase treatment caused excessive loss of $\mathrm{CN}$ that were needed to stabilize $\mathrm{CCP}$, which resulted in no obvious peak that had elevated $\mathrm{Ca}$ and $\mathrm{P}$ contents. Debye plots at these retention times indicated that the weight-average $M_{w}$ for the fraction prepared by trypsin was $17,450 \mathrm{~g} / \mathrm{mol}$. Attempts to estimate the $\mathrm{M}_{\mathrm{w}}$ of the phosphopeptides associated with CCP using sodium dodecyl sulfate-PAGE were not successful, as we did not observe any peptide bands in these gels, presumably because of their low concentration in the isolated, unconcentrated fraction. Assuming that $4 \mathrm{CN}$
\end{abstract}

Received August 23, 2010.

Accepted March 17, 2011.

${ }^{1}$ Corresponding author: jalucey@facstaff.wisc.edu phosphopeptides stabilized each CCP and if the $\mathrm{M}_{\mathrm{w}}$ of each of these phosphopeptides was about $2,500 \mathrm{~g} / \mathrm{mol}$, then the $\mathrm{M}_{\mathrm{w}}$ of $\mathrm{CCP}$ would be around $7,450 \mathrm{~g} / \mathrm{mol}$. This experimental value was close to the theoreticallyderived $\mathrm{M}_{\mathrm{w}}$ of 4,897 and $9,757 \mathrm{~g} / \mathrm{mol}$ for tetrahedron and bi-pyramid shaped objects, respectively, when using the brushite form of calcium phosphate.

Key words: size exclusion chromatography, casein micelle, molecular weight, colloidal calcium phosphate

\section{INTRODUCTION}

Caseins are composed of several phosphorylated proteins, $\alpha_{\mathrm{s} 1^{-}}, \alpha_{\mathrm{s} 2^{-}}, \beta-$, and $\kappa-\mathrm{CN}$, and account for around $80 \%$ of all milk proteins in bovine milk. Casein molecules in milk exist as CN micelles (CM), large (50 300 $\mathrm{nm}$ in diameter), mostly spherical, aggregates. The structure and properties of CM have been extensively studied over the years (Holt, 1992; De Kruif and Holt, 2003; Horne, 2006; Qi, 2007; Fox and Brodkorb, 2008). Initially, most groups considered that micelles were composed of discrete subunits called submicelles; recent models (Holt, 1992; Horne, 1998) suggest that micelles are formed by the aggregation of $\mathrm{CN}$ as a result of protein-protein and colloidal calcium phosphate (CCP) interactions. Although the exact nature of the CM remains controversial, all models agree that CCP plays a critical role in micellar formation and stability.

In the dual-bonding model for the formation and structure of CM proposed by Horne (1998), 2 of the well-known features of individual $\mathrm{CN}$ molecules are described as being critical to micelle formation: its amphiphilic nature (i.e., block copolymers) and a specific Ca-binding motif (i.e., phosphoseryl clusters). The dual-bonding model assigns a specific bonding role to these 2 segments in the assembly of CM. Hydrophobic regions of $\mathrm{CN}$ molecules associate, whereas phosphoseryl motifs of CN crosslink via CCP. This dual-bonding process continues, and the polymeric chain grows until growth is stopped when a size-limiter, $\kappa-\mathrm{CN}$, terminates both the CCP-mediated extension and the hydrophobic interaction pathway (Horne, 1998). The important roles of $\mathrm{CCP}$ in the formation of $\mathrm{CM}$ are as a crosslinker that connects $\mathrm{CN}$ molecules together, 
and as a neutralizer that reduces negative charges on serine phosphorus groups, which produces a favorable environment (reduced electrostatic repulsion) for hydrophobic attraction (Horne, 1998).

Considerable interest and controversy exists regarding the nature of $\mathrm{CCP}$ in milk, with conflicting reports suggesting that this calcium phosphate is an acidic form like brushite (Holt et al., 1982) or a basic form like tricalcium phosphate that is associated with citrate (Pyne and McGann, 1960). The structure of CCP has been described as either amorphous (McGann et al., 1983a,b), lacking an extensive crystal lattice (Irlam et al., 1985), or a small crystalline (solid) material (Horne et al., 2007). Investigations into CCP have revealed that it is present in micelles as small $(2.5-\mathrm{nm})$ granules (McGann et al., 1983a,b); these granules have also been described as nanoclusters (Holt et al., 1996).

Several approaches have been used to prepare a purified CCP fraction. Tryptic digestion of the CN yields phosphopeptides from their polar N-terminal regions that contain clusters of phosphorylated seryl residues (Cross et al., 2005). Digestion of CM with trypsin has been used to prepare CCP-phosphopeptide fractions (Peterson et al., 1958; Berrocal et al., 1989; Juillerat et al., 1989; Ono et al., 1994; Aoki et al., 1998). Rose and Colvin (1966) used papain and alkaline phosphatase to enzymatically digest the $\mathrm{CN}$ in milk. McGann et al. (1983b) used hydrazine extraction to deproteinate milk before performing electron microscopy, infrared spectrum analysis, and x-ray scattering on this CCP fraction. Termine et al. (1973) reported that a hydrazine extraction method did not alter the nature of calcium phosphates. McGann et al. (1983a) used a mixture of proteinases to digest $\mathrm{CN}$ and reported that the total protein content of this fraction greatly decreased.

The molecular aspects of CCP have not been well characterized. For example, only a few attempts have been reported to estimate the molecular weight $\left(\mathbf{M}_{\mathbf{w}}\right)$ of CCP. Ono et al. (1994) digested bovine milk with trypsin to obtain CCP-phosphopeptide fractions, and used gel filtration chromatography to measure the $\mathrm{M}_{\mathrm{w}}$ of the crude CCP preparation. The $\mathrm{M}_{\mathrm{w}}$ of the crude CCP preparation was estimated to be about 170,000 $\mathrm{g} / \mathrm{mol}$, which means that the $\mathrm{M}_{\mathrm{w}}$ of $\mathrm{CCP}$ alone should be less than $170,000 \mathrm{~g} / \mathrm{mol}$ because of the unknown number of trypsinated multiphosphorylated peptides present in the fraction. Holt et al. (1998) prepared artificial calcium phosphate nanoclusters stabilized with $\beta$-CN 4P phosphopeptide (f1-25), and proposed a coreshell model for CCP. Holt et al. (1998) suggested that the CCP core had a mass of $61,000 \mathrm{~g} / \mathrm{mol}$, whereas the shell had an $\mathrm{M}_{\mathrm{w}}$ of $136,000 \mathrm{~g} / \mathrm{mol}$ because of the presence of 48 phosphate centers. Recently, Horne et al. (2007) attempted to estimate the theoretical $M_{w}$ of CCP and reported that it was about 4,898 to approximately $9,757 \mathrm{~g} / \mathrm{mol}$. This $\mathrm{M}_{\mathrm{w}}$ was deduced from an active role for phosphate in the precipitation of the $\mathrm{CN}$-calcium-phosphate mixture, but this calculation has yet to be supported experimentally.

In this study, CCP fractions, prepared by enzymatic digestion with several types of proteinases, were analyzed using size-exclusion chromatography (SEC) coupled with multi-angle laser light scattering (MALLS). Size-exclusion chromatography-MALLS was selected because the use of light scattering for the determination of $\mathrm{M}_{\mathrm{w}}$ does not need calibration (i.e., the $M_{w}$ is determined directly from light scattering principles; Wyatt, 1993). Simulated milk ultrafiltrate (SMUF; Jenness and Koops, 1962) was employed as a mobile phase during chromatography to try to maintain the integrity of CCP during SEC-MALLS. We prepared CCP-phosphopeptide fractions using digestion of CM with trypsin as well as a combination of papain and proteinase because both of these methods have also been previously used to prepare CCP fractions. In this paper, we investigated the weight-average $\mathrm{M}_{\mathrm{w}}$ of $\mathrm{CCP}$ obtained in these preparations and compared the results with previous reports for the $\mathrm{M}_{\mathrm{w}}$ of CCP.

\section{MATERIALS AND METHODS}

\section{Materials}

L-1-Tosylamide-2-phenylethyl chloromethyl ketone (TPCK)-treated trypsin from bovine pancreas (EC 3.4.21.4), papain from Carica papaya (EC 3.4.22.2), and bacterial proteinase from Streptomyces griseus were purchased from Sigma Chemical Co. (St. Louis, MO). Activities (product information, Sigma Chemical Co.) of trypsin, papain, and proteinase were approximately 13,500 units $/ \mathrm{mg}$ [ 1 unit will produce a $\Delta \mathrm{A}_{253}$ of 0.001 per min at $\mathrm{pH} 7.6$ at $25^{\circ} \mathrm{C}$ using $1 \mu \mathrm{mol}$ of N-benzoyl-Larginine ethyl ester (BAEE) as substrate], 11.4 units/ $\mathrm{mg}$ (1 unit corresponds to the amount of enzyme that hydrolyzes $1.0 \mu \mathrm{mol}$ of BAEE per min at $\mathrm{pH} 6.2$ and $25^{\circ} \mathrm{C}$ ), and 4 units/mg [1 unit will hydrolyze $\mathrm{CN}$ to produce color equivalent to $1.0 \mu \mathrm{mol}(181 \mu \mathrm{g})$ of tyrosine per min at $\mathrm{pH} 7.5$ at $37^{\circ} \mathrm{C}$, respectively. Dialysis sac (SnakeSkin pleated dialysis tubing, 10,000 MWCO) was supplied by Pierce Biotechnology, Inc. (Rockford, IL). All of the chemicals used were of analytical grade obtained from Fisher Scientific (Fairlawn, NJ).

\section{Digestion of Milk Samples with Enzymes}

Fresh skim milk that was pasteurized at $73^{\circ} \mathrm{C}$ for 15 s was obtained from the University of Wisconsin-Madison Dairy Plant, and used for preparing samples. First, 
$0.02 \% \mathrm{NaN}_{3}$ was added to skim milk to inhibit bacterial growth. Twenty milligrams of trypsin alone (Ono et al., 1994), or a combination of 2 enzymes, $20 \mathrm{mg}$ of papain and $50 \mathrm{mg}$ of bacterial proteinase (Rose and Colvin, 1966), were added to $100 \mathrm{~mL}$ of skim milk sample. Milk samples with added enzymes were placed in dialysis sacs and dialyzed at room temperature against $4 \mathrm{~L}$ of the same skim milk used for the preparation of the samples. For more complete digestion, the same concentration of these enzymes were added to the dialysis sacs after 1 day, and the dialyzing buffer was changed daily for an additional $3 \mathrm{~d}$ at room temperature $\left(\sim 22^{\circ} \mathrm{C}\right)$. Digested samples were then filtered through a $0.22-$ and $0.1-\mu \mathrm{m}$ filter (Millipore Corp., Bedford, MA).

\section{Chemical Analyses}

The acid-base titration method (Hassan et al., 2004) was used, not only to obtain buffering curves of digested samples, but also to quantify the insoluble (INS) Ca content (i.e., $\mathrm{CN}$ bound) in digested samples from the CCP buffering area. The protein content in samples was measured by the Kjeldahl method (AOAC, 2000). For total $\mathrm{Ca}$ and $\mathrm{P}$ content analyses of milk, samples were dried and ashed, and then ashed samples were solubilized with $25 \% \mathrm{HNO}_{3}$ and diluted to $1 \% \mathrm{HNO}_{3}$ with double-deionized water. The $\mathrm{Ca}$ and $\mathrm{P}$ contents in each SEC fraction were also directly measured without ashing; $0.5 \mathrm{~mL}$ of each fraction collected during chromatography was diluted with $4.5 \mathrm{~mL}$ of $0.1 \% \mathrm{HNO}_{3}$. These samples were fed into an inductively coupled argon plasma emission spectrometer (model Varian Vista-Pro AX; Varian Australia Pty Ltd., Clayton, Victoria, Australia). Wavelengths used for $\mathrm{Ca}$ and $\mathrm{P}$ were 317.9 and $214.9 \mathrm{~nm}$, respectively.

\section{Size-Exclusion Chromatography with Multi-Angle Laser Light Scattering}

Separation of the fraction containing the CCP nanoclusters in enzymatically digested samples was performed by SEC using Superose 6HR 10/30 and Superose 12HR 10/30 columns (Amersham Pharmacia Biotech AB, Uppsala, Sweden) connected in series and attached to a Waters HPLC system (Waters Corp., Milford, MA; Wang and Lucey, 2003). Fresh SMUF at $\mathrm{pH} 6.7$, containing $0.02 \% \mathrm{NaN}_{3}$, was prepared from stock solutions according to Jenness and Koops (1962). The SMUF buffer was prefiltered through a $0.025-\mu \mathrm{m}$ filter (Millipore Corp.), and was used as an elution buffer (buffers used for SEC-MALLS were always filtered through $0.025-\mu \mathrm{m}$ filters to remove any residual dust or particles). The reservoir of SMUF buffer was cooled in an ice bath to prevent calcium phosphate precipitation, and the operation of SEC-MALLS was performed at room temperature $\left(\sim 22^{\circ} \mathrm{C}\right)$. Sample injection volume was $1,000 \mu \mathrm{L}$, and the nominal flow rate was $0.3 \mathrm{~mL} /$ min. Spectrum analysis was performed by a photodiodearray (PDA) detector (Waters Corp.; model 996) operating over the range 200 to $400 \mathrm{~nm}$, with a scanning rate of $1.0 \mathrm{~nm} / \mathrm{s}$ and a resolution of $1.2 \mathrm{~nm}$. Each eluate was collected by fraction collector (Foxy Jr., Teledyne Isco, Inc., Lincoln, NE) every 5 min for approximately $1.5 \mathrm{~mL}$, and total running time was $250 \mathrm{~min}$.

A Dawn-EOS MALLS photometer (Wyatt Technology, Inc., Santa Barbara, CA) fitted with a helium-neon laser $(\lambda=690 \mathrm{~nm})$ and a K5-flow cell, combined with a differential refractive index (DRI) detector (Waters Corp.; model 2410) was used for calculation of the $\mathrm{M}_{\mathrm{w}}$ of the CCP fraction in the digested samples (Wyatt, 1993). Light scattering (LS) data from MALLS, and concentration data from DRI were processed with ASTRA (version 4.70; Wyatt Technology Inc., Santa Barbara, CA), and UV data (224 and $280 \mathrm{~nm}$ ) were processed by Waters Millennium software (version $3.20)$.

\section{Data Treatment}

The Dawn-EOS MALLS photometer simultaneously provides up to $16 \mathrm{LS}$ chromatograms, each at a different scattering angle, for a polymer solute as it emerges from the SEC column (Wyatt, 1993). The data/signal from the DRI detector was used for the determination of concentration. We used a $d n / d c$ value of $0.185 \mathrm{~mL} / \mathrm{g}$ for small peptides, and assumed a second virial coefficient $\left(A_{2}\right)$ of zero (Wen et al., 1996). The $\mathrm{M}_{\mathrm{w}}$ of the CCP fraction eluting in each slice were calculated with a first-order Debye fit (higher order polynomials were also tried but gave a poorer fit to the data). Extrapolating this fitted curve to the $\mathrm{Y}$ intercept provides the $\mathrm{M}_{\mathrm{w}}$. The calibration of LS detectors was performed by measuring the light-scattering intensity of filtered HPLC quality toluene, which has a known Rayleigh ratio at the $90^{\circ}$ angle. The responses of LS intensity of the photo-diodes arrayed around the scattering cell were normalized to the diode at $90^{\circ}$ with an isotropic BSA sample (monomeric BSA with a nominal $\mathrm{M}_{\mathrm{w}}$ of 66 kDa; Lucey et al., 2000).

\section{SDS-PAGE}

To separate the small peptides in each eluate obtained from the SEC column, tricine-SDS-PAGE was performed according to Schägger and von Jagow (1987). Briefly, $16.5 \%$ Tris-tricine gels (Ready Gel precast gels; Bio-Rad Laboratories, Richmond, CA) was cast on an electrophoresis unit (Mini-Protean 3 Cell; Bio- 
Rad Laboratories, Inc., Hercules, CA). Running buffer contained $0.1 \mathrm{M}$ Tris- $\mathrm{HCl}(\mathrm{pH} 8.3), 0.1 \mathrm{M}$ tricine, and $0.1 \%$ SDS. Samples and polypeptide markers (Bio-Rad Laboratories, Inc., Hercules, CA) were diluted with sample buffer containing $0.25 \mathrm{M}$ Tris- $\mathrm{HCl}(\mathrm{pH} 6.8), 1 \%$ SDS, and $2 \% 2$-mercaptoethanol, and boiled at $95^{\circ} \mathrm{C}$ for 4 min. Electrophoresis was carried out at a constant voltage of $120 \mathrm{~V}$ for $2 \mathrm{~h}$.

\section{RESULTS}

\section{Chemical Composition of Digested Samples}

Trypsin, or a combination of papain and proteinase, was added to skim milk to try to remove most $\mathrm{CN}$ but leave the phosphopeptides intact that were involved in stabilizing the CCP nanoclusters. As shown in Table 1 , the protein content (including large peptides) of skim milk was decreased from 3.32 to 0.92 and $0.36 \%$ in trypsinated and papain-proteinase-treated skim milk samples, respectively. As expected, a combination of papain and proteinase caused the greater loss of $\mathrm{CN}$ from CCP than trypsin treatment alone. This is in agreement with previous results by McGann et al. (1983a) and Holt et al. (1986). Total Ca and P contents in both enzyme-treated samples were lower than in the untreated samples. The contents of total $\mathrm{Ca}$ and $\mathrm{P}$ in milk before enzyme digestion were 107 and 87 $\mathrm{mg} / 100 \mathrm{~g}$ of milk, respectively. However, after enzyme digestion, the total $\mathrm{Ca}$ and $\mathrm{P}$ contents were 100 and $80 \mathrm{mg} / 100 \mathrm{~g}$ of milk for trypsinated samples, and 85 and $72 \mathrm{mg} / 100 \mathrm{~g}$ of milk for papain-proteinase-treated samples, respectively. The $\mathrm{pH}$ value of milk did not change during digestion/dialysis as a result of using the same skim milk to dialyze the samples.

To estimate the number of intact CCP nanoclusters retained after enzyme treatment and dialysis, samples were analyzed by the acid-base titration method to determine INS Ca content. This technique would allow us to evaluate if the nature of the CCP material had changed during treatment (which would be revealed as altered buffering profiles, not just a decrease in peaks). As shown in Figure 1, the shapes of the acidbase buffering curves for trypsinated (Figure 1b) and papain-proteinase-treated samples (Figure 1c) were very similar to that obtained for skim milk (Figure 1a), although the buffering peak at $\mathrm{pH}$ of approximately 5.0 during acidification was lower in the enzyme-treated samples. The INS Ca content in these samples is shown in Table 2. The INS Ca contents in both enzyme-treated samples (70 and $58 \mathrm{mg} / 100 \mathrm{~g}$ of milk in trypsinated and papain-proteinase-treated samples, respectively) were lower than the initial INS Ca content $(75 \mathrm{mg} / 100$ $\mathrm{g}$ of milk). This indicates that a significant number of CCP nanoclusters survived severe digestion/dialysis, although the loss of CCP was greater in the papainproteinase-treated samples. To try to determine the effect of using SMUF as the mobile phase in SEC, we also dialyzed the trypsinated samples against SMUF for $4 \mathrm{~d}$. A substantial decrease in the CCP buffering peak (Figure 1d) and a decrease in the concentration of total Ca and INS Ca occurred (Table 2) after dialysis against SMUF. However, because the total running time in SEC-MALLS experiments (where SMUF was used as the buffer) was only $250 \mathrm{~min}$, the loss of CCP nanoclusters was likely to be much lower during SEC separation compared with our 4-d dialysis experiment. For our SEC-MALLS analysis, the enzymatically digested samples were dialyzed against skim milk and not SMUF. It should be noted that the SEC-MALLS measurements were run after the dialysis step, so if nanoclusters survived the dialysis step, then a few more hours in the SEC column with the SMUF mobile phase was not going to greatly degrade them.

\section{Molecular Weight of the CCP Nanocluster Fraction}

During SEC, the MALLS system detected large aggregated material that eluted at $40 \mathrm{~min}$ (data not shown), which appeared to be large residual fat globules (Lucey et al., 2000). After filtration of the sample through 0.1 $\mu \mathrm{m}$, the size of this peak was greatly decreased (Figures $2 \mathrm{~b}$ and $3 \mathrm{~b}$ ). In all subsequent SEC-MALLS experiments, digested samples were first filtered through a $0.1-\mu \mathrm{m}$ membrane for improved removal of residual fat. Simulated milk ultrafiltrate was used as the mobile phase to try to ensure the integrity of CCP nanoclusters during separation. We used SMUF as a mobile phase instead of ultrafiltrate permeate because of possible contamination from other materials in ultrafiltrate permeate (e.g.,

Table 1. Chemical composition for skim milk and enzyme-treated skim milk ${ }^{1}$

\begin{tabular}{lccc}
\hline Sample & $\begin{array}{c}\text { Protein } \\
(\%)\end{array}$ & $\begin{array}{c}\text { Total Ca } \\
(\mathrm{mg} / 100 \mathrm{~g})\end{array}$ & $\begin{array}{c}\text { Total P } \\
(\mathrm{mg} / 100 \mathrm{~g})\end{array}$ \\
\hline Skim milk & $3.32 \pm 0.04$ & $107 \pm 1$ & $87 \pm 5$ \\
Trypsinated skim milk & $0.92 \pm 0.02$ & $100 \pm 1$ & $80 \pm 5$ \\
Papain-proteinase-treated skim milk & $0.36 \pm 0.01$ & $85 \pm 2$ & $72 \pm 2$ \\
\hline
\end{tabular}

${ }^{1}$ Values are average $(\mathrm{n}=3) \pm$ standard deviation. 
Table 2. Total and insoluble Ca contents in skim milk and enzyme-treated skim milk ${ }^{1}$

\begin{tabular}{lcc}
\hline Sample & $\begin{array}{c}\text { Total Ca } \\
(\mathrm{mg} / 100 \mathrm{~g})\end{array}$ & $\begin{array}{c}\text { Insoluble Ca } \\
(\mathrm{mg} / 100 \mathrm{~g})\end{array}$ \\
\hline Skim milk & 108 & 75 \\
Trypsinated skim milk dialyzed against skim milk & 99 & 70 \\
Papain-proteinase-treated skim milk dialyzed against skim milk & 87 & 58 \\
\hline${ }^{1}$ The insoluble Ca content was determined from colloidal calcium phosphate (CCP) buffering area using the \\
acid-base titration method of Hassan et al. (2004).
\end{tabular}

peptides) to the responses from MALLS, DRI, and UV detectors. Each fraction obtained from the DRI detector was collected over 5 -min intervals, and the fractions were analyzed for their $\mathrm{Ca}$ and $\mathrm{P}$ contents.

The results for the $\mathrm{Ca}$ and $\mathrm{P}$ contents in each fraction during SEC of trypsinated skim milk samples are given in Figure 2a. One peak was observed at retention times between 100 to 110 min that contained higher amounts of $\mathrm{Ca}$ and $\mathrm{P}$ than the SMUF baseline. This peak was suggestive as a candidate for the CCP nanocluster fraction. The MALLS signals and DRI responses during SEC are given in Figure $2 \mathrm{~b}$, and the $\mathrm{M}_{\mathrm{w}}$ corresponding to this retention time was calculated using ASTRA software (Figure 2b). The calculated weight-average $\mathrm{M}_{\mathrm{w}}$ was $17,450 \mathrm{~g} / \mathrm{mol}$ (Table 3). Absorbances for this peak at 2 wavelengths, 224 and $280 \mathrm{~nm}$, are presented in Figure 2c. At retention times between 100 to 110 min, the absorbance values at $224 \mathrm{~nm}$ were much higher than those at $280 \mathrm{~nm}$. Holt et al. (1986) reported that phosphopeptides involved in stabilizing CCP contained very low levels of aromatic AA (Table 4). Thus, the absorbance at $280 \mathrm{~nm}$ should be low for the phosphopeptide fraction.

The SEC profiles in skim milk that was treated with papain-proteinase are shown in Figure 3. We determined the $\mathrm{Ca}$ and $\mathrm{P}$ contents of each fraction that was collected (Figure 3a), and report the responses from MALLS, DRI (Figure 3b), and UV at 224 and $280 \mathrm{~nm}$ (Figure 3c). Unfortunately, it was hard to see any peak that had levels of $\mathrm{Ca}$ and $\mathrm{P}$ contents greater than those
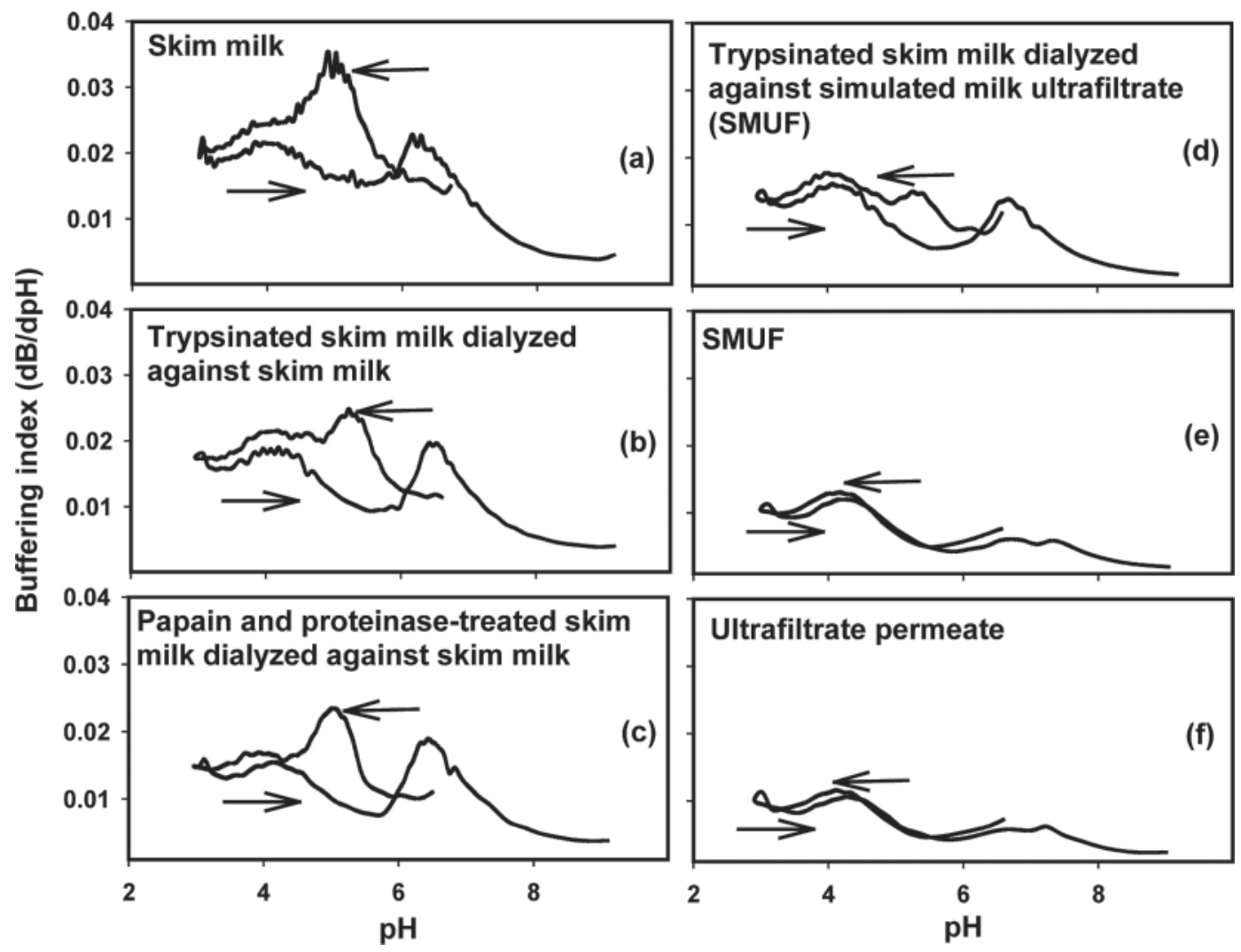

Figure 1. Buffering capacity of various experimental samples that are first acidified from initial $\mathrm{pH}(\sim 6.7)$ to $\mathrm{pH} 3.0 \mathrm{with} 0.5 \mathrm{~N} \mathrm{HCl}$ and then alkalized to $\mathrm{pH} 9.0$ with $0.5 \mathrm{~N} \mathrm{NaOH}$. Arrows indicate direction of titration. 


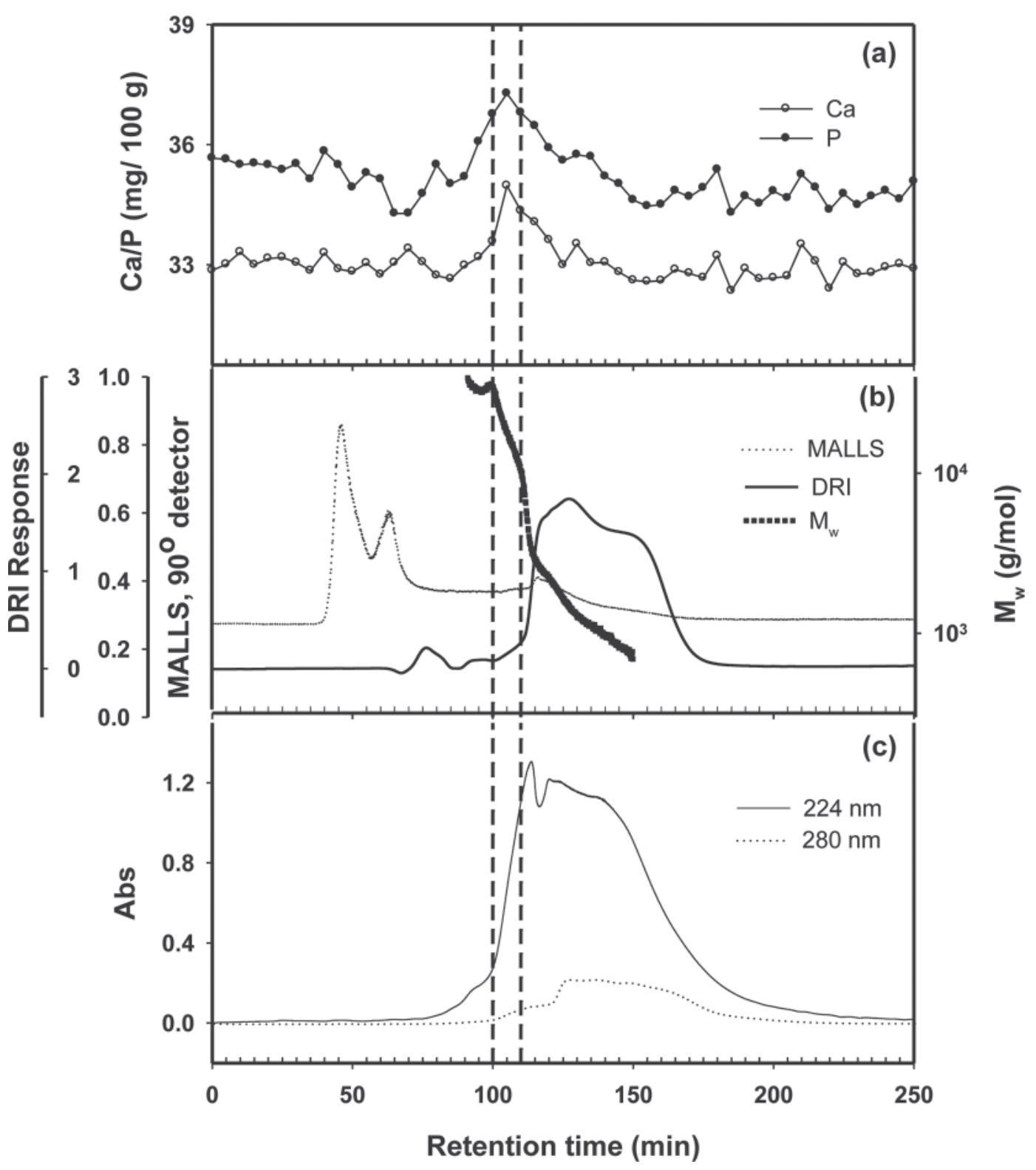

Figure 2. Size-exclusion chromatography (SEC) elution profiles for a trypsinated skim milk sample that was prefiltered through a 0.1- $\mu$ m membrane; (a) Ca and P content in each fraction, (b) multi-angle laser light scattering (MALLS) $90^{\circ}$ detector and differential refractive index (DRI), and (c) UV responses at 224 and $280 \mathrm{~nm}$. Columns used were Superose 6 and $12 \mathrm{HR}$; flow rate, $0.3 \mathrm{~mL} / \mathrm{min}$; elution buffer, simulated milk ultrafiltrate (SMUF). Vertical dashed lines indicate likely fraction containing colloidal calcium phosphate $(\mathrm{CCP}) . \mathrm{M}_{\mathrm{w}}=\mathrm{molecular}$ weight .

present in the SMUF baseline (Figure 3a). The absence of a peak was probably because of a greater loss of $\mathrm{Ca}$ and $\mathrm{P}$ in this sample (Table 2). Presumably, the combination of papain and proteinase caused excessive degradation of phosphopeptides because these enzymes have broad specificity and we also observed a very low protein content in this sample after digestion/dialysis $(\sim 0.36 \%)$. Retention times for the possible CCP nanocluster fraction were chosen for the papain-proteinase digested sample as being from 96 to $98 \mathrm{~min}$, as we observed that the UV absorbance at $224 \mathrm{~nm}$ was high relative to a very low absorbance at $280 \mathrm{~nm}$. A plot of $\mathrm{M}_{\mathrm{w}}$ as a function of elution time is shown in Figure 3b. The $\mathrm{M}_{\mathrm{w}}$ of the peak between 96 and 98 min was 23,940 $\mathrm{g} / \mathrm{mol}$ (Table 3 ).

The sizes of peptides present in the samples, prepared using trypsin and papain-proteinase, as well as in 2 selected fractions, were analyzed by SDS-PAGE, and are shown in Figure 4. Trypsin $\left(\mathrm{M}_{\mathrm{w}}=24,000 \mathrm{~g} /\right.$ mol) and papain $\left(\mathrm{M}_{\mathrm{w}}=23,000 \mathrm{~g} / \mathrm{mol}\right)$-proteinase $\left(\mathrm{M}_{\mathrm{w}}\right.$ 
$=16,000 \sim 27,000 \mathrm{~g} / \mathrm{mol}$ ) that were dialyzed against milk are shown in lanes 1 and 4, respectively. Autolysis of trypsin was observed in lane 1, and papain and proteinase also digested each other as shown in lane 4 . It should be noted that the enzymes (trypsin, papain, and proteinase) that were added for digestion purposes were not removed from the digested milk samples. These enzymes were clearly seen in lanes 2 and 5 in the tryptic and papain-proteinase-treated milk samples, respectively. The pattern of products from trypsin-treated skim milk samples (lane 2 in Figure 4) showed that not all proteins present in skim milk were hydrolyzed into the expected small size range. The skim milk sample contains whey proteins, which includes high- $\mathrm{M}_{\mathrm{w}}$ serum proteins like immunoglobulins, BSA, and lactoferrin, which can be observed in lane 2 in Figure 4 . The various sizes of peptides from papain-proteinase-treated samples were also observed in lane 5 in Figure 4, but the added enzymes, as well as products from self- and cross-digestion, probably contribute to most of the

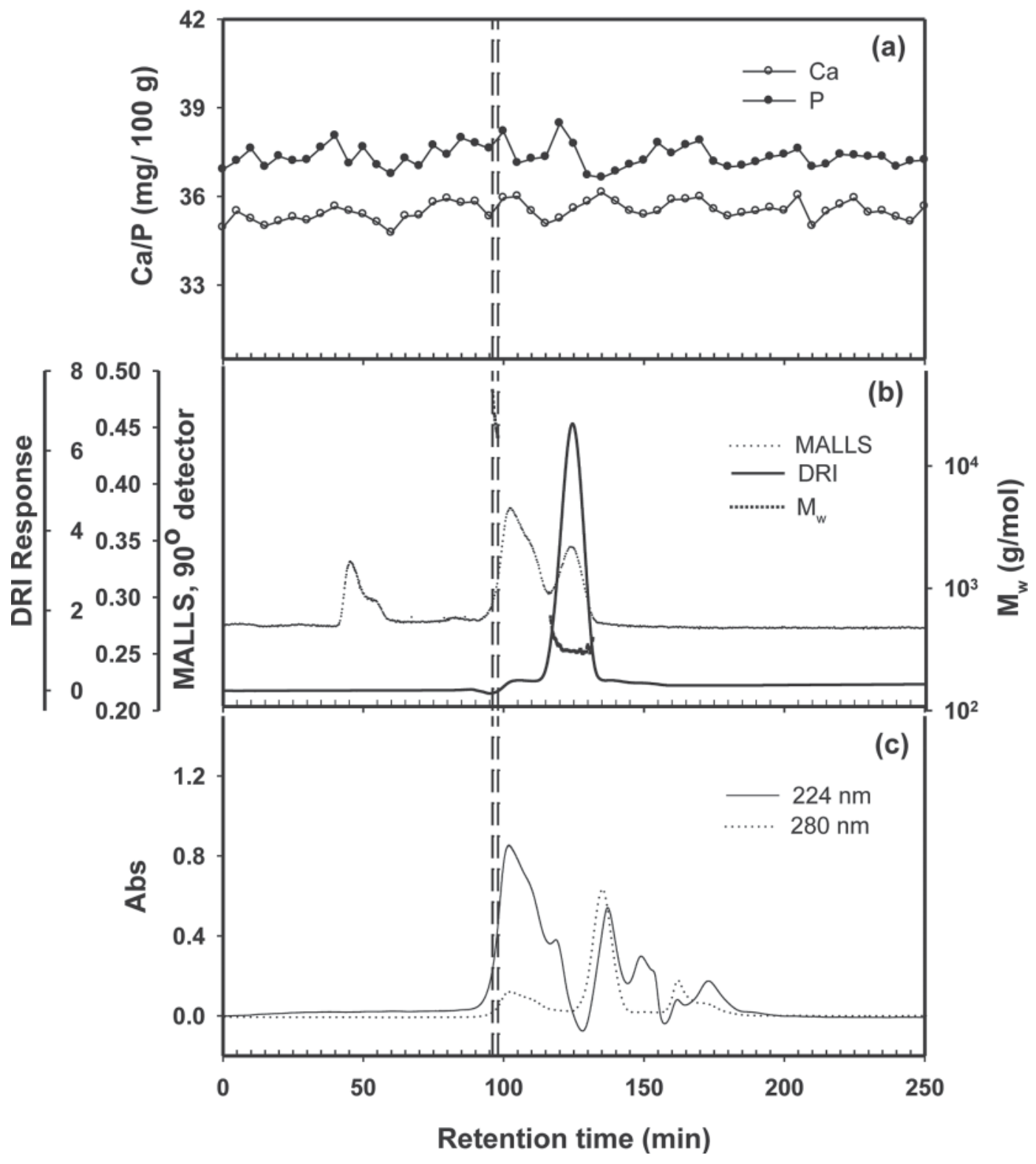

Figure 3. Size-exclusion chromatography (SEC) elution profiles for a papain-proteinase-treated skim milk sample that was prefiltered through a 0.1- $\mu \mathrm{m}$ membrane; (a) Ca and $\mathrm{P}$ content in each fraction, (b) multi-angle laser light scattering (MALLS) $90^{\circ}$ detector and differential refractive index (DRI), and (c) UV responses at 224 and $280 \mathrm{~nm}$. Columns used were Superose 6 and 12 HR (Amersham Pharmacia Biotech $\mathrm{AB}$, Uppsala, Sweden); flow rate, $0.3 \mathrm{~mL} / \mathrm{min}$; elution buffer, simulated milk ultrafiltrate (SMUF). Vertical dashed lines indicate likely fraction containing colloidal calcium phosphate $(\mathrm{CCP}) . \mathrm{M}_{\mathrm{w}}=$ molecular weight. 
Table 3. Weight-average molecular weight $\left(\mathrm{M}_{\mathrm{w}}, \mathrm{g} / \mathrm{mol}\right)$ for the colloidal calcium phosphate (CCP) nanocluster (with associated phosphopeptides) peak obtained in enzyme-treated skim milk ${ }^{1}$

\begin{tabular}{ll}
\hline Sample & \multicolumn{1}{c}{$\mathrm{M}_{\mathrm{w}}$} \\
\hline Trypsinated sample & $17,450(0.8)$ \\
Papain-proteinase-treated sample & $23,940(8)$ \\
\hline${ }^{1}$ Values in parentheses are relative errors in percent.
\end{tabular}

peptides. No obvious peptide bands of low $\mathrm{M}_{\mathrm{w}}(\sim 3,000$ $\mathrm{g} / \mathrm{mol}$ ) were observed in lanes 3 and 6 from the fractions obtained from trypsinated and papain-proteinasetreated samples, respectively. This was probably a result of the very low concentration of these peptides because we did not attempt to concentrate our samples. One large protein band, shown in lane 3, could be a result of contamination from a previous fraction (incomplete separation during SEC). Extensive digestion of phosphopeptides by papain-proteinase could be also responsible for the absence of any obvious peptides in lane 6 in Figure 4.

\section{DISCUSSION}

We recently attempted to estimate the $\mathrm{M}_{\mathrm{w}}$ of a CCP nanocluster by assuming that the nanocluster was not spherical, had some crystalline form, that each phosphoserine cluster involved in stabilizing CCP consisted of at least 3 phosphoserine residues, and that the type of CCP found in CM was brushite (Horne et al., 2007). Several possible shapes of the CCP nanocluster were considered, including tetrahedron and bi-pyramid, which have 4 and 6 faces, respectively, which would need to be capped by phosphoserine clusters. Thus, the theoretical $\mathrm{M}_{\mathrm{w}}$ for the nanocluster was estimated to be $4,898 \mathrm{~g} / \mathrm{mol}$ for a tetrahedron $\left(36 \mathrm{CaHPO}_{4}\right)$, or as large as $9,757 \mathrm{~g} / \mathrm{mol}$ if the shape was a bi-pyramid (72 $\mathrm{CaHPO}_{4}$ ), the next larger form (Horne et al., 2007).
To experimentally support our theoretically-derived $\mathrm{M}_{\mathrm{w}}$ of the CCP nanocluster, SEC was used to separate the CCP nanocluster-containing fraction and MALLS used to measure the $\mathrm{M}_{\mathrm{w}}$ of the fraction contents. During dialysis of enzyme-treated samples, some of the smaller molecules (less than 10,000 $\mathrm{g} / \mathrm{mol}$ ) resulting from the hydrolysis of the proteins were removed through the dialysis membrane, which was indicated by the decrease in the protein content (Table 1). Nonetheless, a variety of peptides larger than $10,000 \mathrm{~g} / \mathrm{mol}$ was present in the 2 digested samples (lanes 3 and 5 in Figure 4), probably because of the incomplete digestion of whey proteins and the presence of the (added) residual enzymes. Our SDS-PAGE pattern in lane 2 (Figure 4) was similar to that reported by Ono et al. (1994). We cannot be sure what fraction of peptides smaller than $10,000 \mathrm{~g} / \mathrm{mol}$ shown in lane 2 (Figure 4) were associated with CCP nanoclusters. The peptides removed through the dialysis sac probably included some phosphoserine peptides. This could have been responsible for the lower total $\mathrm{Ca}$ and total $\mathrm{P}$ contents in enzyme-treated samples compared with the untreated milk (Table 1). The digestion was achieved under very careful conditions, but the small loss of CCP nanoclusters was unavoidable, as shown in Table 2. The papain-proteinase-treated samples resulted in greater loss of CCP nanoclusters than did trypsinated samples, which might indicate that peptides of a certain size are required to protect/ stabilize CCP nanoclusters. It appeared that CCP nanoclusters exhibit considerable stability during digestion when dialyzed against milk (Tables 2 and 3 ). The MALLS signals (Figures $2 \mathrm{~b}$ and $3 \mathrm{~b}$ ) of the fractions rich in $\mathrm{Ca}$ and $\mathrm{P}$ were very low. This is probably because of the very low quantity of CCP nanoclusters. In the preparation of CCP nanoclusters from skim milk samples, we did not concentrate the CCP nanocluster fraction because we were concerned that any treatment (i.e., redispersion of separated $\mathrm{CM}$ in ultrafiltrate to

Table 4. Amino acid sequences of putative trypsin-digested multiphosphopeptides ${ }^{1}$

\begin{tabular}{|c|c|c|}
\hline CN type ${ }^{2}$ & Trypsin-derived phosphopeptide sequence ${ }^{3}$ & $\mathrm{M}_{\mathrm{W}}^{4}$ \\
\hline \multirow{2}{*}{$\alpha_{\mathrm{S} 1}-\mathrm{CN}(15)$} & $\mathrm{E}_{59}$ MEAES $_{64} \mathbf{I S}_{66} \mathbf{S}_{67} \mathbf{S}_{68}$ GEIVPNS $_{75}$ VEQK $_{79}$ & $2,250.4$ \\
\hline & $\mathrm{V}_{106} \mathrm{PQLEIVPNS}_{115} \mathrm{AEER}_{119}$ & $1,580.7$ \\
\hline \multirow{3}{*}{$\alpha_{\mathrm{S} 2}-\mathrm{CN}(20)$} & $\mathrm{N}_{46}$ ANEEEYSIGS $_{56} \mathbf{S}_{57} \mathbf{S}_{58}$ EES $_{61}$ AEVATEEVK $_{70}$ & $2,688.6$ \\
\hline & $\mathrm{E}_{126} \mathrm{QLS}_{129} \mathrm{TS}_{131} \mathrm{EENSK}_{136}$ & $1,251.2$ \\
\hline & $\mathrm{T}_{138}$ VDMES $_{143}$ TEVFTK $_{149}$ & $1,386.5$ \\
\hline
\end{tabular}

\footnotetext{
${ }^{1}$ This table was generated using CLC Protein Workbench 2 (CLC bio, Cambridge, MA).

${ }^{2}$ The number of cleavage sites by trypsin is in parentheses.

${ }^{3}$ Bold characters indicate location of serine phosphate. Underlined characters are aromatic AA.

${ }^{4}$ Molecular weight (does not include P).
} 


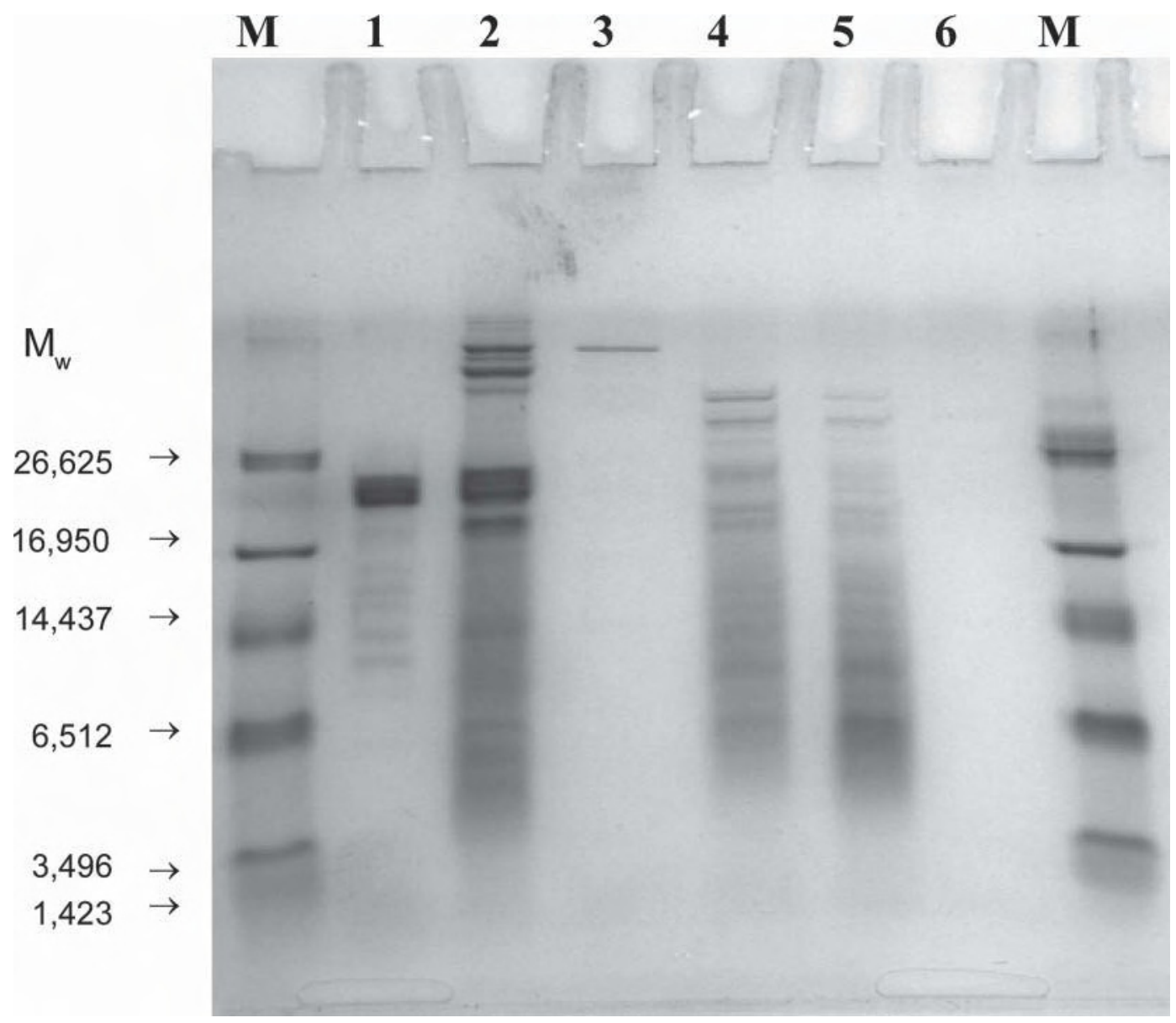

Figure 4. Sodium dodecyl sulfate-PAGE patterns of samples and fractions obtained from trypsin- or papain-proteinase-treated skim milk samples. $\mathrm{M}=$ molecular marker; 1 = trypsin enzyme that was dialyzed against milk; 2 = trypsin-treated samples; $3=$ fraction obtained from trypsin-treated samples that had high contents of $\mathrm{Ca}$ and $\mathrm{P} ; 4=$ papain-proteinase dialyzed against milk; $5=$ papain-proteinase-treated sample; $6=$ fraction obtained from papain-proteinase-treated sample that exhibited similar UV absorbance to that observed for trypsinated samples. $\mathrm{M}_{\mathrm{w}}=$ molecular weight.

obtain a high concentration of CCP nanoclusters), could potentially upset the integrity and change the $\mathrm{M}_{\mathrm{w}}$ of CCP nanoclusters.

In our study, trypsin was chosen because of the high specific cleavage of peptide bonds at the carboxyl adjacent to Lys (K) and Arg (R). Table 4 shows AA sequences of several phosphopeptides that trypsin could potentially produce from the 4 different types of $\mathrm{CN}$. As seen in Table 4, $\alpha_{\mathrm{s} 1^{-}}, \alpha_{\mathrm{s} 2^{-}}, \beta$-, and $\kappa$-CN have 15, 20, 11, and 10 potential tryptic cleavage sites, respectively. Fortunately, phosphoserine clusters that are putatively involved in CCP nanoclusters are still present in these peptides. Assuming that 1 peptide (59 79) of $\alpha_{\mathrm{s} 1}$-CN, 2 peptides (1 21 and 46 70) of $\alpha_{\mathrm{s} 2^{-}} \mathrm{CN}$, and 1 peptide $(1 \sim 25)$ of $\beta-\mathrm{CN}$ are involved in CCP nanoclusters, these phosphoserine peptides that are involved in CCP nanoclusters have an average $\mathrm{M}_{\mathrm{w}}$ of $2,542 \mathrm{~g} / \mathrm{mol}$. Because the $\mathrm{M}_{\mathrm{w}}$ of fractions rich in $\mathrm{Ca}$ and $\mathrm{P}$ contents from the tryptic samples was about $17,450 \mathrm{~g} / \mathrm{mol}$ and
4 phosphopeptides were previously mentioned as likely to be involved in stabilizing $\mathrm{CCP}$, the $\mathrm{M}_{\mathrm{w}}$ of a CCP nanocluster could be $17,450-(2,542 \times 4)=7,282 \mathrm{~g} /$ mol. It should be noted that if trypsin hydrolysis of CN were not complete (i.e., not all available trypsin cleavage sites were hydrolyzed), then the $\mathrm{M}_{\mathrm{w}}$ of the stabilizing phosphopeptides would be larger, which, in turn, would decrease our estimate of the $\mathrm{M}_{\mathrm{w}}$ of the CCP nanocluster.

In the experiment with papain-proteinase, the $\mathrm{M}_{\mathrm{w}}$ of our selected fraction was about $23,940 \mathrm{~g} / \mathrm{mol}$. We cannot be certain how these 2 enzymes hydrolyzed CN molecules, as these enzymes have a very broad specificity and their peptide products cannot be predicted. In addition, each CCP nanocluster can be stabilized by phosphoserine clusters from several types of CN. Therefore, the susceptibility for each nanocluster to these 2 enzymes is likely to differ [i.e., some nanoclusters could survive but others (with greater $\mathrm{CN}$ digestion) were 
no longer protected by phosphoserine peptides and dissolved]. A lower INS Ca content was also found in papain-proteinase-treated samples compared with the trypsinated samples (Table 2). This may explain why no obvious peak was observed for concentrations of $\mathrm{Ca}$ and $\mathrm{P}$ in fractions during SEC-MALLS (Figure 3a). Holt et al. (1986) reported that $70 \%$ of serine residues in their calcium phosphate-rich material (prepared with porcine fibrinolysin, protease type XIV from Streptomyces griseus, potato acid phosphatase, and papain type IV) were phosphoserine residues. Therefore, we think that some of the CCP nanocluster survived after extensive digestion. Holt (1992) suggested that only about $20 \%$ of CCP was lost during most digestion/dialysis experiments but the loss of CCP is likely to depend on the extent of digestion of the phosphopeptides. The $\mathrm{M}_{\mathrm{w}}$ of a nanocluster in this fraction may depend on the size of phosphopeptides. The size of peptides after digestion could be from as small as $5 \times 135=675 \mathrm{~g} / \mathrm{mol}$, if the peptide consisted of at least $5 \mathrm{AA}$, to as large as 2,542 $\mathrm{g} / \mathrm{mol}$. Presumably, the size of a phosphopeptide chain segment influences its ability to stabilize a nanocluster with very small peptides, probably losing this stabilization ability. Thus, we assume that the likely size of the stabilizing peptides could be approximately 2,500 g/ mol. The $\mathrm{M}_{\mathrm{w}}$ of a nanocluster stabilized by 4 phosphopeptides of $\mathrm{M}_{\mathrm{w}} 2,500 \mathrm{~g} / \mathrm{mol}$ could be $23,940-(2,500 \times$ 4) $=13,940 \mathrm{~g} / \mathrm{mol}$.

We obtained 2 different $\mathrm{M}_{\mathrm{w}}$ for the CCP nanocluster with the different approaches to enzymatic digestion. This difference could be because of different modes of proteolysis and preferential dissolution of nanoclusters in the samples. For the papain-proteinase sample, the absence of a peak with an elevated $\mathrm{Ca} / \mathrm{P}$ content makes this approach to estimating the $\mathrm{M}_{\mathrm{w}}$ for CCP less reliable compared with the trypsin-treated sample.

It is also possible that nanoclusters could exhibit a size distribution. In the recent model for the CCP nanocluster (Horne et al., 2007), the shape of the CCP nanocluster was selected as a tetrahedron or bi-pyramid, and the number of phosphoserine residues in one phosphoserine cluster was selected as 3 or 4 . Our selections for these 2 factors could change our theoretical $M_{w}$ of CCP nanocluster. However, the $\mathrm{M}_{\mathrm{w}}$ obtained by the 2 different enzyme digestion systems was comparable to the range of theoretical $\mathrm{M}_{\mathrm{w}}$ obtained by Horne et al. (2007).

The $\mathrm{M}_{\mathrm{w}}$ of the crude CCP fraction calculated by Ono et al. (1994) includes an unknown number of phosphoserine peptides. The $\mathrm{M}_{\mathrm{w}}$ of the crude CCP preparation was estimated to be about $170,000 \mathrm{~g} / \mathrm{mol}$, which means that the $\mathrm{M}_{\mathrm{w}}$ of CCP alone should be less than 170,000 $\mathrm{g} / \mathrm{mol}$ because of the unknown number of trypsinated multiphosphorylated peptides, which are often 2,500 to $3,000 \mathrm{~g} / \mathrm{mol}$ each. In the gel filtration experiments of Ono et al. (1994), the peak identified as the likely crude CCP-containing fraction was poorly resolved from the other tryptic digestion materials so it is possible that it could be contaminated by other peptides or even fragments derived from the autodigestion of trypsin (Maroux and Desnuelle, 1969). Ono et al. (1994) also prepared phosphoserine-stabilized CCP nanoclusters but the reported $\mathrm{M}_{\mathrm{w}}$ of these nanoclusters depended on the casein source used to prepare the phosphoserine peptides. One possible explanation is that the size of nanoclusters depends on the available numbers of phosphate clusters but Ono et al. (1994) did not indicate the concentration of phosphopeptides used for these experiments. Ono et al. (1994) estimated the $\mathrm{M}_{\mathrm{w}}$ of the CCP fractions based on retention times and used a calibration curve obtained with proteins of known $\mathrm{M}_{\mathrm{w}}$. Molecular weight standards used to calibrate gel filtration should have similar shape and physical properties to the target macromolecule and it is unclear if the retention times obtained for $\mathrm{CCP}$ can be accurately converted into $M_{w}$ using predictions from protein $M_{w}$ standards.

Holt et al. (1998) estimated that 48 peptides were involved in their shell model for CCP. The thickness of this shell was estimated to be only $1.6 \mathrm{~nm}$ (Holt et al., 1998), which appears too small to successfully accommodate such a large number of peptides each having a $\mathrm{M}_{\mathrm{w}}$ of approximately $3,000 \mathrm{~g} / \mathrm{mol}$ (Horne, 2006). It should be noted that a minimum of 3 phosphate groups were reported as being needed to crosslink caseins with CCP (Aoki et al., 1992); it is not clear why more than 10 times that number of phosphopeptides would be needed to stabilize CCP, as was suggested by Holt et al. (1998).

Using the number of peptides as 48 (Holt et al., 1998) and the $\mathrm{M}_{\mathrm{w}}$ for the crude $\mathrm{CCP}$ fraction (containing both CCP and the associated phosphopeptides) that Ono et al. (1994) estimated, the $\mathrm{M}_{\mathrm{w}}$ of CCP could be calculated as $170,000-(48 \times 3,000 \mathrm{~g} / \mathrm{mol}$ of phosphopeptide $)=26,000 \mathrm{~g} / \mathrm{mol}$, which is less than half of the estimated $(61,000 \mathrm{~g} / \mathrm{mol}) \mathrm{M}_{\mathrm{w}}$ of CCP obtained by Holt et al. (1998). If only $4 \mathrm{CN}$ are involved in a single CCP nanocluster, as suggested by Horne et al. (2007), it makes the estimation of Ono et al. (1994) much larger. Our experimental values are very different (and much smaller) than those reported by Ono et al. (1994) and Holt et al. (1998).

In the review of De Kruif and Holt (2003), an average CM was given the following physical properties: radius $(R)$ of $108 \mathrm{~nm}, \mathrm{M}_{\mathrm{w}}$ of $\mathrm{CM}\left(M_{m}\right)$ of $720 \times 10^{6}$ Da, weight fraction of CCP nanoclusters $(w)$ of 0.07 , 
and spacing between nanoclusters $(\lambda)$ of $18 \mathrm{~nm}$. Using these estimates the $\mathrm{M}_{\mathrm{w}}$ of CCP nanoclusters $\left(M_{c}\right)$ can be calculated as follows (De Kruif and Holt, 2003):

$$
M_{C}=\frac{\lambda^{3} 3 w M_{m}}{4 \pi R^{3}} .
$$

The $\mathrm{M}_{\mathrm{w}}$ of CCP nanoclusters $\left(\mathrm{M}_{\mathrm{c}}\right)$ is thereby estimated as 56,000 Da. The 18-nm spacing (size of the heterogeneities in CM or correlation length from scattering experiments) is the distance from center to center of nanoclusters, so we believe that the calculation should instead be based on a radius of $9 \mathrm{~nm}$ around each nanocluster center. Recalculating with a $\lambda=9$ $\mathrm{nm}$ results in an $\mathrm{M}_{\mathrm{w}}$ of CCP nanoclusters of 7,000 Da, which is close to our estimated $\mathrm{M}_{\mathrm{w}}$ for CCP. We estimate that about 1,100 of these nanocluster spheres could be fitted in $\mathrm{CM}$ of radius $108 \mathrm{~nm}$, if they are close-packed to about $60 \%$. Considering that this calculation involves gross approximations and the averaging involved in this approach, the estimate for the $\mathrm{M}_{\mathrm{w}}$ of $\mathrm{CCP}$ derived from some reported properties of $\mathrm{CM}$ is a very reasonable figure relative to both our theoretically and experimentally derived numbers.

\section{CONCLUSIONS}

We measured the $\mathrm{M}_{\mathrm{w}}$ of fractions that contained $\mathrm{CCP}$ nanoclusters obtained from CM. The $\mathrm{M}_{\mathrm{w}}$ of CCP nanoclusters was estimated to be $7,282 \mathrm{~g} / \mathrm{mol}$ for trypsinated samples and 13,940 g/mol for papain-proteinase-treated samples. Allowing for a likely size frequency distribution of the nanoclusters, the theoretically derived $\mathrm{M}_{\mathrm{w}}$ of 4,897 to $9,757 \mathrm{~g} / \mathrm{mol}$ was comparable to the experimentally measured one with SEC-MALLS. Using our experimental $\mathrm{M}_{\mathrm{w}}$ of around 7,000 $\mathrm{g} / \mathrm{mol}$, and assuming that nanoclusters form a multi-faceted solid, such as a tetrahedron- or bi-pyramid-shaped crystalline entity, it can be calculated that CCP nanoclusters would have a size of around $3 \mathrm{~nm}$ (Horne et al., 2007). These results are compatible with models for the CM (Holt, 1992; Horne 1998) that involve small ( $3-\mathrm{nm})$ CCP nanoclusters as critical crosslinks between $\mathrm{CN}$. An improved understanding of the nature of $\mathrm{CCP}$ is useful to the dairy industry, as this material plays a key role in $\mathrm{CN}$ functionality in various dairy products.

\section{ACKNOWLEDGMENTS}

The financial support of Dairy Research Institute (Rosemont, IL) is greatly appreciated.

\section{REFERENCES}

AOAC. 2000. Official Methods of Analysis. 17th ed. Association of Official Analytical Chemists, Gaithersburg, MD.

Aoki, T., T. Nakano, T. Iwashita, Y. Sugimoto, H. R. Ibrahim, Y. Toba, S. Aoe, and I. Nakajima. 1998. Preparation and characterization of micellar calcium phosphate-casein phosphopeptide complex. J. Nutr. Sci. Vitaminol. (Tokyo) 44:447-456.

Aoki, T., T. Umeda, and Y. Kako. 1992. The least number of phosphate groups for crosslinking of casein by colloidal calcium phosphate. J. Dairy Sci. 75:971-975.

Berrocal, R., S. Chanton, M. A. Juillerat, B. Pavillard, J.-C. Scherz, and R. Jost. 1989. Tryptic phosphopeptides from whole casein. II. Physicochemical properties related to the solubilization of calcium. J. Dairy Res. 56:335-341.

Cross, K. J., N. L. Huq, J. E. Palamara, J. W. Perich, and E. C. Reynolds. 2005. Physicochemical characterization of casein phosphopeptide-amorphous calcium phosphate nanocomplexes. J. Biol. Chem. 280:15362-15369.

De Kruif, C. G., and C. Holt. 2003. Casein micelle structure, functions and interactions. Pages 233-276 in Advanced Dairy Chemistry: Volume 1: Proteins. 3rd ed. P. F. Fox and P. L. H. McSweeney, ed. Kluwer Academic/Plenum Publishers, New York, NY.

Fox, P. F., and A. Brodkorb. 2008. The casein micelle: Historical aspects, current concepts and significance. Int. Dairy J. 18:677-684.

Hassan, A., M. E. Johnson, and J. A. Lucey. 2004. Changes in the proportions of soluble and insoluble calcium during the ripening of Cheddar cheese. J. Dairy Sci. 87:854-862.

Holt, C. 1992. Structure and stability of bovine casein micelles. Adv Protein Chem. 43:63-151.

Holt, C., D. T. Davies, and A. J. R. Law. 1986. Effects of colloidal calcium phosphate content and free calcium ion concentration in the milk serum on the dissociation of bovine casein micelles. J. Dairy Res. 53:557-572.

Holt, C., S. S. Hasnain, and D. W. L. Hukins. 1982. Structure of bovine milk calcium phosphate determined by X-ray absorption spectroscopy. Biochim. Biophys. Acta 719:299-303.

Holt, C., P. A. Timmins, N. Errington, and J. Leaver. 1998. A coreshell model of calcium phosphate nanoclusters stabilized by $\beta$-casein phosphopeptides, derived from sedimentation equilibrium and small-angle X-ray and neutron-scattering measurements. Eur. J. Biochem. 252:73-78.

Holt, C., M. Wahlgren, and T. Drakenberg. 1996. Ability of a $\beta$-casein phosphopeptide to modulate the precipitation of calcium phosphate by forming amorphous dicalcium phosphate nanoclusters. Biochem. J. 314:1035-1039.

Horne, D. S. 1998. Casein interactions: Casting light on the black boxes, the structure in dairy products. Int. Dairy J. 8:171-177.

Horne, D. S. 2006. Casein micelle structure: Models and muddles. Curr. Opin. Colloid Interface Sci. 11:148-153.

Horne, D. S., J. A. Lucey, and J. Choi. 2007. Casein interaction: Does the chemistry really matter? Pages $155-166$ in Food Colloids: Selfassembly and Material Science. E. Dickinson and M. Leser, ed. Royal Society of Chemistry, Cambridge, UK.

Irlam, J. C., C. Holt, S. S. Hasnain, and D. W. Hukins. 1985. Comparison of the structure of micellar calcium phosphate in milk from six species by extended X-ray absorption fine structure spectroscopy. J. Dairy Res. 52:267-273.

Jenness, R., and J. Koops. 1962. Preparation and properties of a salt solution which simulates milk ultrafiltrate. Neth. Milk Dairy J. $16: 153-163$.

Juillerat, M. A., R. Baechler, R. Berrocal, S. Chanton, J.-C. Scherz, and R. Jost. 1989. Tryptic phosphopeptides from whole casein. I. Preparation and analysis by fast protein liquid chromatography. J. Dairy Res. 56:603-611.

Lucey, J. A., M. Srinivasan, H. Singh, and P. A. Munro. 2000. Characterization of commercial and experimental sodium caseinates by multiangle laser light scattering and size-exclusion chromatography. J. Agric. Food Chem. 48:1610-1616. 
Maroux, S., and P. Desnuelle. 1969. On some autolyzed derivatives of bovine trypsin. Biochim. Biophys. Acta 181:59-72.

McGann, T. C. A., W. Buchheim, R. D. Kearney, and T. Richardson. 1983a. Composition and ultrastructure of calcium phosphatecitrate complexes in bovine milk systems. Biochim. Biophys. Acta 760:415-420.

McGann, T. C. A., R. D. Kearney, W. Buchheim, A. S. Posner, F. Betts, and N. C. Blumenthal. 1983b. Amorphous calcium phosphate in casein micelles of bovine milk. Calcif. Tissue Int. 35:821-823.

Ono, T., T. Ohotawa, and Y. Takagi. 1994. Complexes of casein phosphopeptides and calcium phosphate prepared from casein micelles by tryptic digestion. Biosci. Biotechnol. Biochem. 58:1376-1380.

Peterson, R. F., L. W. Nauman, and T. L. McMeekin. 1958. The separation and amino acid composition of a pure phosphopeptone prepared from $\beta$-casein by the action of trypsin. J. Am. Chem. Soc. 80:95-99.

Pyne, G. T., and T. C. A. McGann. 1960. The colloidal calcium phosphate of milk. II. Influence of citrate. J. Dairy Res. 27:9-17.

Qi, P. X. 2007. Studies of casein micelle structure: The past and the present. Lait 87:363-383
Rose, D., and J. Colvin. 1966. Internal structure of casein micelles from bovine milk. J. Dairy Sci. 49:351-355.

Schägger, H., and G. von Jagow. 1987. Tricine-sodium dodecyl sulfatepolyacrylamide gel electrophoresis for the separation of proteins in the range from 1 to $100 \mathrm{kDa}$. Anal. Biochem. 166:368-379.

Termine, J. D., E. D. Eanes, D. J. Greenfield, M. U. Nylen, and R. A. Harper. 1973. Hydrazine-deproteinated bone mineral. Physical and chemical properties. Calcif. Tissue Res. 12:73-90.

Wang, T., and J. A. Lucey. 2003. Use of multi-angle laser light scattering and size-exclusion chromatography to characterize the molecular weight and types of aggregates present in commercial whey protein products. J. Dairy Sci. 86:3090-3101.

Wen, J., T. Arakawa, and J. S. Philo. 1996. Size-exclusion chromatography with on-line light-scattering, absorbance, and refractive index detectors for studying proteins and their interactions. Anal. Biochem. 240:155-166.

Wyatt, P. J. 1993. Light scattering and the absolute characterization of macromolecules. Anal. Chim. Acta 272:1-40. 